\title{
Development of Molecular Assays for Detection of Stenocarpella maydis and Stenocarpella macrospora in Corn
}

\author{
M. P. Romero and K. A. Wise, Department of Botany and Plant Pathology, Purdue University, West Lafayette, IN 47907
}

\begin{abstract}
Romero, M. P., and Wise, K. A. 2015. Development of molecular assays for detection of Stenocarpella maydis and Stenocarpella macrospora in corn. Plant Dis. 99:761-769.

The causal agents of Diplodia ear rot are two species of the Stenocarpella genus, S. macrospora and S. maydis. In addition to ears, both pathogens can infect leaves and stalks, and both are present in most cornproduction regions around the world. It is difficult to visually distinguish between the two pathogens based on plant symptoms and fungal signs. To facilitate accurate and rapid pathogen identification, polymerase chain reaction (PCR) assays were developed for identification of each species. Species-specific primers of 18 to 20 nucleotides in length were designed, targeting a portion of the internal transcribed spacer

(ITS) region of the fungal genome for conventional and real-time PCR assays. The conventional PCR method successfully amplified a single 1.7-kb and 800-bp fragment for each S. maydis and S. macrospora isolate, respectively. The real-time method was performed using SYBR green dye, and detection of each specific target pathogen was successfully obtained. In total, $82 \mathrm{~S}$. maydis and $15 \mathrm{~S}$. macrospora isolates were tested to evaluate the reproducibility of these primers. Both methods provide a rapid and specific tool for the detection of Stenocarpella spp.
\end{abstract}

Stenocarpella macrospora (Earle) B. Sutton and S. maydis (Berk.) B. Sutton, the only two species included in the Stenocarpella genus $(9,12,47,48)$, have been identified as causal agents of Diplodia ear rot, Diplodia leaf streak, and Diplodia stalk rot (53). Both species are able to infect ears, stalks, and leaves $(47,48)$ and, under specific conditions, these fungi can produce mycotoxins $(10,45,55)$. S. maydis is recognized as one of the most persistent and important ear rot pathogens in the world (41). Typically, S. macrospora has been more significant in tropical and subtropical areas $(15,20,24)$; however, the disease is commonly present in the United States, and increases in disease incidence have been observed across the Midwest in recent years $(3,52)$.

Visually distinguishing between symptoms caused by these two species is challenging (6). S. macrospora produces long elliptical gray-green lesions with yellowish margins on leaves. Concentric zones are evident in the lesion around the point of infection origin. Pycnidia are typically observed in the older part of the lesion $(19,24,53)$. Foliar lesions caused by $S$. maydis are oval and smaller than those caused by $S$. macrospora (19) and pycnidia production is less abundant across the lesion. Both diseases may be confused with other common corn foliar diseases, including northern corn leaf blight (caused by Exserohilum turcicum; 1) and Goss's bacterial leaf blight (Clavibacter michiganensis subsp. nebraskensis; 56). When ears are infected, both species can colonize the ear with white, cottony mycelia. Black pycnidia can be observed on the husk or on the kernel surface $(6,13,24)$. Crop rotation and tillage are currently the only reliable methods for disease management. Hybrids with complete resistance to these diseases are not known, although some hybrids may be less susceptible than others.

In 2012, Diplodia ear rot, leaf streak, and stalk rot resulted in a combined loss of 0.97 million metric tons in the United States and Ontario, Canada (31). In addition to yield loss, in some subtropical and tropical corn production areas, cases of diplodiosis, a neuromycotoxicosis of livestock, have been reported and associated with $S$. maydis $(17,23,28,35,37)$. Diplodiatoxin and diplonine have also

Corresponding author: K. A. Wise; E-mail: kawise@ purdue.edu

Accepted for publication 15 December 2014.

http://dx.doi.org/10.1094/PDIS-09-14-0917-RE

(C) 2015 The American Phytopathological Society been associated with diplodiosis but these mycotoxins do not always cause the neurological signs associated with diplodiosis symptoms in livestock animals and, therefore, it is believed that the main causal agents responsible for this mycotoxicosis are still unknown $(45,46,55)$. $S$. macrospora produces diplosporin and diplodiol, two mycotoxins that affect small animals $(10,18)$. Field outbreaks were reported only in South Africa (16,28) until 1964, when Darvall reported a possible outbreak in Australia. Recently, Argentina (32) and Brazil (38) reported cases of animal poisoning by diplodiosis. Although there have been no reports of diplodiosis in the United States $(22,51)$, corn grain is tested for the presence of these pathogens when exported to other countries. S. maydis is considered a regulated nonquarantine pest (RNQP) in Brazil, due to the negative impact it has on corn production $(2,44)$.

Currently, $S$. maydis is considered a major pathogen throughout the corn-producing regions in the United States and, although $S$. macrospora is currently considered a minor pathogen in the United States, Latterell et al. (19) concluded that this pathogen could compromise corn production in humid areas of the United States. The distribution and prevalence of S. macrospora in the United States is not well known. Previous studies have focused on determining morphological differences between these two pathogens. There are clear differences in conidial dimensions and number of septa between the two species. S. maydis conidia are 15 to 34 by 5 to $8 \mu \mathrm{m}$, with 0 to 2 septae. S. macrospora conidia are almost triple the size of $S$. maydis conidia, being 55 to 106 by 6 to $14 \mu \mathrm{m}$ and with 0 to 3 septae $(12,24,47,48)$. There are also color variances between young and old cultures of each species when grown on potato dextrose agar (PDA) $(8,25,36)$. Initially, both species have a white, cottony appearance on the media; however, after 2 weeks, $S$. maydis cultures turn grayish to dark brown. Cultures of $S$. macrospora maintain the original white appearance. Another distinguishable characteristic is that $S$. maydis reportedly produces higher numbers of pycnidia in culture (30). Pycnidia production of $S$. macrospora in culture increases when mycelium is removed from surface of culture. However, $S$. macrospora requires more time to develop pycnidia and, frequently, pycnidia are embedded in the media or at the edge of the plate $(15,19,29)$, making it difficult to obtain conidia for identification (2).

Previous studies described the use of the polymerase chain reaction (PCR) method to identify Stenocarpella spp. $(33,57)$. Primers designed for these assays were based on the internal transcribed spacer (ITS) region for Stenocarpella spp., and these assays were able to differentiate Stenocarpella spp. from other fungal 
species but were not specific enough to differentiate between the two Stenocarpella spp. (2).

According to Lievens et al. (21), the absence of an effective and accurate method to detect and identify pathogens is one of the major limitations of plant disease management. Although Stenocarpella spp. can be distinguished based on a combination of morphological and cultural factors, these techniques are time consuming and are not conducive to the accurate and rapid diagnosis required for regulatory agencies that monitor corn seed pathogens to prevent pathogen establishment in new areas and to monitor grain for the presence of pathogens that produce mycotoxins. S. maydis is considered an RNQP in Brazil, due to the negative impact it has on

Table 1. Isolate code, year, and collection site of Stenocarpella spp. and other pathogenic species used in this study

\begin{tabular}{|c|c|c|c|}
\hline Isolate code & Pathogen & Year & County, state \\
\hline $1-1-1$ & Stenocarpella maydis & 2010 & Tippecanoe, IN \\
\hline $1-1-3$ & S. maydis & 2010 & Tippecanoe, IN \\
\hline $1-2-4$ & S. maydis & 2010 & Tippecanoe, IN \\
\hline $1-3-3$ & S. maydis & 2010 & Tippecanoe, IN \\
\hline $1-6-2$ & S. maydis & 2010 & Tippecanoe, IN \\
\hline $1-11-2$ & S. maydis & 2010 & Tippecanoe, IN \\
\hline $1-11-4$ & S. maydis & 2010 & Tippecanoe, IN \\
\hline $1-13-2$ & S. maydis & 2010 & Tippecanoe, IN \\
\hline $1-14-4$ & S. maydis & 2010 & Tippecanoe, IN \\
\hline $1-18-1$ & S. maydis & 2010 & Tippecanoe, IN \\
\hline $1-19-1$ & S. maydis & 2010 & Tippecanoe, IN \\
\hline $1-20-4$ & S. maydis & 2010 & Tippecanoe, IN \\
\hline $2-2-1$ & S. maydis & 2010 & Tippecanoe, IN \\
\hline $2-3-1$ & S. maydis & 2010 & Tippecanoe, IN \\
\hline $2-4-1$ & S. maydis & 2010 & Tippecanoe, IN \\
\hline $2-6-2$ & S. maydis & 2010 & Tippecanoe, IN \\
\hline $2-7-4$ & S. maydis & 2010 & Tippecanoe, IN \\
\hline $2-8-1$ & S. maydis & 2010 & Tippecanoe, IN \\
\hline $2-13-1$ & S. maydis & 2010 & Tippecanoe, IN \\
\hline $2-14-1$ & S. maydis & 2010 & Tippecanoe, IN \\
\hline $2-16-1$ & S. maydis & 2010 & Tippecanoe, IN \\
\hline $2-20-1$ & S. maydis & 2010 & Tippecanoe, IN \\
\hline $3-1-1$ & S. maydis & 2010 & Tippecanoe, IN \\
\hline $3-2-2$ & S. maydis & 2010 & Tippecanoe, IN \\
\hline $3-3-1$ & S. maydis & 2010 & Tippecanoe, IN \\
\hline $3-3-2$ & S. maydis & 2010 & Tippecanoe, IN \\
\hline $3-4-4$ & S. maydis & 2010 & Tippecanoe, IN \\
\hline $3-5-2$ & S. maydis & 2010 & Tippecanoe, IN \\
\hline $3-6-4$ & S. maydis & 2010 & Tippecanoe, IN \\
\hline $3-8-2$ & S. maydis & 2010 & Tippecanoe, IN \\
\hline $3-9-1$ & S. maydis & 2010 & Tippecanoe, IN \\
\hline $3-9-3$ & S. maydis & 2010 & Tippecanoe, IN \\
\hline $3-9-4$ & S. maydis & 2010 & Tippecanoe, IN \\
\hline $3-10-1$ & S. maydis & 2010 & Tippecanoe, IN \\
\hline $3-10-2$ & S. maydis & 2010 & Tippecanoe, IN \\
\hline $3-11-1$ & S. maydis & 2010 & Tippecanoe, IN \\
\hline $3-11-2$ & S. maydis & 2010 & Tippecanoe, IN \\
\hline $3-12-3$ & S. maydis & 2010 & Tippecanoe, IN \\
\hline $3-12-4$ & S. maydis & 2010 & Tippecanoe, IN \\
\hline 1b. 1 & S. maydis & 2011 & Tippecanoe, IN \\
\hline $1 \mathrm{~b} .2$ & S. maydis & 2011 & Tippecanoe, IN \\
\hline $2 b .2$ & S. maydis & 2011 & Tippecanoe, IN \\
\hline $3 a .1$ & S. maydis & 2011 & Tippecanoe, IN \\
\hline $4 \mathrm{~b} .1$ & S. maydis & 2011 & Tippecanoe, IN \\
\hline $7 a .1$ & S. maydis & 2011 & Tippecanoe, IN \\
\hline 8 b. 1 & S. maydis & 2011 & Tippecanoe, IN \\
\hline $8 b .2$ & S. maydis & 2011 & Tippecanoe, IN \\
\hline $9 b .1$ & S. maydis & 2011 & Tippecanoe, IN \\
\hline 10a.1 & S. maydis & 2011 & Tippecanoe, IN \\
\hline 10a.2 & S. maydis & 2011 & Tippecanoe, IN \\
\hline 4a.1.1 & S. maydis & 2011 & Indiana \\
\hline 4a.1.2 & S. maydis & 2011 & Indiana \\
\hline $3 b .1$ & S. maydis & 2011 & Indiana \\
\hline \multicolumn{4}{|c|}{ (continued on next column) } \\
\hline
\end{tabular}

corn production, and corn is routinely screened for presence of the pathogen $(2,44)$. In fact, Casa et al. (6) reported that seed infected with Stenocarpella spp. was responsible for introducing the pathogen into areas in Brazil where it was not previously established. Currently, molecular assays for detecting and distinguishing Stenocarpella spp. are lacking. The objective of this study was to design and validate conventional and real-time PCR assays for Stenocarpella spp.

\section{Materials and Methods}

Fungal isolates and growth conditions. In total, $82 \mathrm{~S}$. maydis isolates and $15 \mathrm{~S}$. macrospora isolates collected in the United States

Table 1. (continued from preceding column)

\begin{tabular}{|c|c|c|c|}
\hline Isolate code & Pathogen & Year & County, state \\
\hline 1.2 & S. maydis & 2012 & Tippecanoe, IN \\
\hline 1.4 & S. maydis & 2012 & Tippecanoe, IN \\
\hline 2 & S. maydis & 2012 & Tippecanoe, IN \\
\hline 2.1 & S. maydis & 2012 & Tippecanoe, IN \\
\hline 3.1 & S. maydis & 2012 & Tippecanoe, IN \\
\hline 3.2 & S. maydis & 2012 & Tippecanoe, IN \\
\hline 3.3 & S. maydis & 2012 & Tippecanoe, IN \\
\hline 3.4 & S. maydis & 2012 & Tippecanoe, IN \\
\hline 4.1 & S. maydis & 2012 & Tippecanoe, IN \\
\hline 5.1 & S. maydis & 2012 & Tippecanoe, IN \\
\hline 5.2 & S. maydis & 2012 & Tippecanoe, IN \\
\hline 6 & S. maydis & 2012 & Tippecanoe, IN \\
\hline 7.1 & S. maydis & 2012 & Tippecanoe, IN \\
\hline 8 & S. maydis & 2012 & Tippecanoe, IN \\
\hline 9 & S. maydis & 2012 & Tippecanoe, IN \\
\hline 5 & S. maydis & 2013 & Tippecanoe, IN \\
\hline 8 & S. maydis & 2013 & Tippecanoe, IN \\
\hline 10 & S. maydis & 2013 & Knox, IN \\
\hline 13 & S. maydis & 2013 & Knox, IN \\
\hline 15.1 & S. maydis & 2013 & Howard, MO \\
\hline 15.2 & S. maydis & 2013 & Howard, MO \\
\hline 44 & S. maydis & 2013 & Cayugo, NY \\
\hline 45 & S. maydis & 2013 & Tippecanoe, IN \\
\hline 1 & S. maydis & 2014 & Gibson, TN \\
\hline 2 & S. maydis & 2014 & Gibson, TN \\
\hline 3 & S. maydis & 2014 & Gibson, TN \\
\hline 5 & S. maydis & 2014 & Gibson, TN \\
\hline 6 & S. maydis & 2014 & Gibson, TN \\
\hline 7 & S. maydis & 2014 & Gibson, TN \\
\hline 1a.1.1 & S. macrospora & 2011 & Indiana \\
\hline 1a.1.2 & S. macrospora & 2011 & Indiana \\
\hline P11-2.1a.1 & S. macrospora & 2011 & Kosciusko, IN \\
\hline P11-2.1a.2 & S. macrospora & 2011 & Kosciusko, IN \\
\hline $4 a .2$ & S. macrospora & 2011 & Indiana \\
\hline $4 c .1 .1$ & S. macrospora & 2011 & Indiana \\
\hline 10a.2 & S. macrospora & 2011 & Indiana \\
\hline $10.1 \mathrm{~b}$ & S. macrospora & 2011 & Indiana \\
\hline 1a & S. macrospora & 2012 & Tippecanoe, IN \\
\hline $1 b$ & S. macrospora & 2012 & Tippecanoe, IN \\
\hline $4 b$ & S. macrospora & 2012 & Tippecanoe, IN \\
\hline 1 & S. macrospora & 2013 & Indiana \\
\hline $2.1 \mathrm{a}$ & S. macrospora & 2013 & Jennings, IN \\
\hline 2.2 & S. macrospora & 2013 & Jennings, IN \\
\hline 4 & S. macrospora & 2014 & Gibson, TN \\
\hline ET & Exserohilum turcicum & 2012 & Tippecanoe, IN \\
\hline $\mathrm{Fv}$ & Fusarium verticillioides & 2012 & Indiana \\
\hline $\mathrm{Fg}$ & Fusarium graminearum & 2012 & Indiana \\
\hline Af & Aspergillus flavus & & Urbana, IL \\
\hline $\mathrm{Cmn}$ & $\begin{array}{l}\text { Clavibacter michiganensis } \\
\text { subsp. Nebraskensis }\end{array}$ & 2008 & Pulaski, IN \\
\hline $\mathrm{Mp}$ & Macrophomina phaseolina & 2011 & Grant, WI \\
\hline $\mathrm{Cg}$ & Colletotrichum graminicola & 2012 & Illinois \\
\hline Ps & Phoma spp. & 2012 & Hamilton, IN \\
\hline $\mathrm{Dp}$ & Diplodia pinea & 2012 & Tippecanoe, IN \\
\hline
\end{tabular}


were included in this study (Table 1). Other pathogenic species that commonly infect corn or are closely related to the Stenocarpella genus were included to assess assay validity (Table 1). Stenocarpella spp. isolates were obtained from corn kernels and corn leaves collected between 2010 and 2014 from fields in Illinois, Indiana, Missouri, New York, Tennessee, and Wisconsin. Isolates were obtained from plant tissue by disinfecting leaves with $5 \%$ commercial bleach (a.i. $5.05 \%$ sodium hypochlorite) and Tween 20 (Bio-Rad Laboratories, Hercules, CA) for $10 \mathrm{~s}$. Tissue was washed twice with water, dried for $4 \mathrm{~h}$, and transferred to PDA. Cultures were stored at $28^{\circ} \mathrm{C}$ under 12-h light and dark cycles until pycnidia were visible (approximately 7 days). A single pycnidium was hand picked with a sterile needle and placed into a 1.5-ml Flex-Eppendorf tube (Eppendorf AG, Hamburg, Germany) with $150 \mu$ l of double distilled $\mathrm{H}_{2} \mathrm{O}$. After agitation, four drops of the suspension were transferred with a sterilized pipette to water agar, containing Bacto agar (Becton, Dickinson and Company, Sparks, MD) at $20 \mathrm{~g} /$ liter. Plates were incubated at room temperature for $24 \mathrm{~h}$ under dark conditions. Single germinated spores were picked and transferred to natural oatmeal agar (NOA) (40). Plates were stored at $28^{\circ} \mathrm{C}$ under 12-h light and dark cycles until the plate was fully colonized (approximately 7 days). Once a single-spore culture was obtained, a 5-mm plug was transferred to a new NOA plate already containing sterilized filter paper $\left(8\right.$ by $8 \mathrm{~cm}$ ). Plates were placed again at $28^{\circ} \mathrm{C}$ under 12-h light and dark cycles until the filter paper was fully colonized and pycnidia production was visible (approximately 15 days). Filter paper was removed from the plate with a sterile forceps and transferred to new, empty petri dish. The filter paper was completely dried, placed inside an envelope covered with foil paper, and stored at $-20^{\circ} \mathrm{C}$ until further use.

DNA extraction. Pure cultures from storage were subcultured on fresh NOA plates. Plates were incubated at $28^{\circ} \mathrm{C}$ under 12 -h light and dark cycles for 7 days, after which approximately $40 \mathrm{mg}$ of fresh mycelium was collected by scraping from the colony surface. DNA was extracted from each isolate by a cetyltrimethyl ammonium bromide (CTAB) protocol derived from Saghai-Maroof et al. (42) and stored in nuclease-free sterile water at $-20^{\circ} \mathrm{C}$. DNA also was extracted from corn kernels and stalks infected by S. maydis in 2014 and from kernels and leaves infected by $S$. macrospora in 2014. DNA extraction from corn plant tissue also followed the CTAB protocol. DNA concentration was measured with a Nanodrop 1000 spectrophotometer (Thermo Fisher Scientific, Wilmington, DE). For conventional and real-time PCR assays, DNA concentrations were adjusted to $10 \mathrm{ng} / \mu \mathrm{l}$.

ITS PCR and sequencing. The ITS regions of Stenocarpella spp. were amplified with ITS1F (CTTGGTCATTTACAGGAAGTAA; 14) and ITS4 (TCCTCCGCTTATTGATATGC; 54) primers. PCR amplifications were carried out in a $25-\mu 1$ reaction volume containing $1 \mu \mathrm{l}$ of template DNA (various DNA concentrations), $0.20 \mathrm{mM}$ each deoxynucleoside triphosphate (Promega Corp., Madison WI), 4 U of Taq DNA polymerase (New England BioLabs Inc., Ipswich, MA), 1× PCR buffer (New England BioLabs Inc.), $0.60 \mu \mathrm{M}$ each forward and reverse primer, and $16 \mu \mathrm{l}$ of nucleasefree sterile water. PCR was conducted with a AB 2720 Thermal Cycler (Applied Biosystems, Foster City, CA) with the following program: an initial heating cycle of $95^{\circ} \mathrm{C}$ for $2 \mathrm{~min} ; 30$ cycles of denaturation at $95^{\circ} \mathrm{C}$ for $15 \mathrm{~s}$, annealing at $55^{\circ} \mathrm{C}$ for $30 \mathrm{~s}$, and extension at $72^{\circ} \mathrm{C}$ for $1.5 \mathrm{~min}$; and a 10 -min final extension at $72^{\circ} \mathrm{C}$. Each total product volume $(10 \mu \mathrm{l})$ was loaded on a $1 \%(\mathrm{wt} / \mathrm{vol})$ agarose gel in $1501 \times$ Tris-acetate-EDTA buffer and stained with ethidium bromide. The gels were run at $50 \mathrm{~V}$ for $40 \mathrm{~min}$ and visualized using a UV-transilluminator FBTI-88 (Thermo Fisher Scientific Inc., Waltham, MA). PCR products were extracted from gels, purified, and sent to the Purdue Genomics Facility for sequencing. DNA sequences were BLAST analyzed to a database constructed from a partial genome assembly. The ITS region was located on a 7.8-kb contig (GenBank accession number KP164561). The sequence of this contig was used to identify two specific sets of primers for $S$. maydis for both conventional and real-time PCR assays. The sequence of the amplified fragments from S. macrospora was aligned with the $S$. maydis sequence, and a single set of primers for this species was designed to use in both conventional and real-time PCR assays. Both species-specific sets of primers (Table 2) were synthesized by Integrated DNA Technologies (Coralville, IA).

Conventional PCR for the diagnosis of Stenocarpella spp. To determine the optimal annealing temperature of each primer set, temperature gradient PCR was carried out using a Mastercycler pro $S$ (Eppendorf AG) with an annealing temperature range of 52 to $63^{\circ} \mathrm{C}$ for $S$. macrospora and 54 to $65^{\circ} \mathrm{C}$ for $S$. maydis. The optimal annealing temperatures for $S$. macrospora and S. maydis were 57 and $60^{\circ} \mathrm{C}$, respectively. One negative control, containing nuclease-free sterile water instead of DNA, was included with each species assay.

For $S$. maydis, PCR were conducted in a $20-\mu 1$ reaction volume containing template DNA at $10 \mathrm{ng} / \mu \mathrm{l}, 0.25 \mathrm{mM}$ each deoxynucleoside triphosphate (Promega Corp.), Taq DNA polymerase (New England BioLabs Inc.) at $4 \mathrm{U} / \mu \mathrm{l}, 1 \times$ PCR buffer (New England BioLabs Inc.), $0.75 \mu \mathrm{M}$ each forward and reverse primer (Table 2), and $11 \mu \mathrm{l}$ of nuclease-free sterile water (Thermo Fisher Scientific Inc., Waltham, MA). Fragments were amplified using the Smay.F/Smay.R primers (Table 2) under the following program: an initial heating cycle of $95^{\circ} \mathrm{C}$ for $2 \mathrm{~min} ; 35$ cycles of denaturation at $95^{\circ} \mathrm{C}$ for $30 \mathrm{~s}$, annealing at $60^{\circ} \mathrm{C}$ for $30 \mathrm{~s}$, and extension at $72^{\circ} \mathrm{C}$ for $1 \mathrm{~min}$; and a 10-min final extension at $72^{\circ} \mathrm{C}$.

For S. macrospora, PCR were conducted in a $20-\mu 1$ reaction volume containing template DNA at $10 \mathrm{ng} / \mu \mathrm{l}, 0.25 \mathrm{mM}$ each deoxynucleoside triphosphate (Promega Corp.), Taq DNA polymerase (New England BioLabs Inc.) at $4 \mathrm{U} / \mu \mathrm{l}, 1 \times$ PCR buffer (New England BioLabs Inc.), $0.25 \mu \mathrm{M}$ forward primer (Table 2), $0.75 \mu \mathrm{M}$ reverse primer (Table 2), and $12 \mu 1$ of nuclease-free sterile water (Thermo Fisher Scientific Inc., Waltham, MA). Fragments were amplified using the Smac.F/Smac.R primers (Table 2) under the following program: an initial heating cycle of $95^{\circ} \mathrm{C}$ for $2 \mathrm{~min}$; 30 cycles of denaturation at $95^{\circ} \mathrm{C}$ for $30 \mathrm{~s}$, annealing at $57^{\circ} \mathrm{C}$ for $30 \mathrm{~s}$, and extension at $72^{\circ} \mathrm{C}$ for $1 \mathrm{~min}$; and a 10 -min final extension at $72^{\circ} \mathrm{C}$.

Following PCR, amplified products were separated via gel electrophoresis and visualized as described above. Each reaction was performed three times. All amplified PCR products were resequenced for verification.

Real-time PCR for the diagnosis of Stenocarpella spp. PCR assays were performed using a LightCycler 480 Instrument (Roche Diagnostics Corporation, Hague Road, IN). For S. maydis, realtime PCR was conducted in a $20-\mu l$ volume reaction mix which included template DNA at $10 \mathrm{ng} / \mu \mathrm{l}, 1 \times \mathrm{i}$ Taq Universal SYBR Green Supermix (Bio-Rad Laboratories), $0.10 \mu \mathrm{M}$ forward primer, $0.60 \mu \mathrm{M}$ reverse primer, and $8.6 \mu \mathrm{l}$ of nuclease-free sterile water (Thermo Fisher Scientific Inc., Waltham, MA). Isolates tested using the RT.Smay.F/RT.Smay.R primers were run as follows: $95^{\circ} \mathrm{C}$ for $2 \mathrm{~min}$, followed by 35 cycles of $95^{\circ} \mathrm{C}$ for $30 \mathrm{~s}, 60^{\circ} \mathrm{C}$ for $30 \mathrm{~s}$, and $72^{\circ} \mathrm{C}$ for $1 \mathrm{~min}$. The thermal profile for melting curve analysis consisted of a denaturation for $5 \mathrm{~s}$ at $95^{\circ} \mathrm{C}$, lowered to $55^{\circ} \mathrm{C}$ for $1 \mathrm{~min}$, then increased to $97^{\circ} \mathrm{C}$ with continuous fluorescence readings.

In total, 15 isolates of $S$. macrospora were amplified in a reaction volume of $20 \mu \mathrm{l}$ which included template DNA at $10 \mathrm{ng} / \mu \mathrm{l}, 1 \times \mathrm{iTaq}$ Universal SYBR Green Supermix (Bio-Rad Laboratories), $0.25 \mu \mathrm{M}$ forward primer, $0.75 \mu \mathrm{M}$ reverse primer, and $7 \mu \mathrm{l}$ of nucleasefree sterile water (Thermo Fisher Scientific Inc., Waltham, MA). These 15 isolates were tested with the same primers (RT.Smac.F/RT. Smac.R) and thermal cycling settings as those for the conventional PCR. The thermal profile for melting curve analysis was the same as for S. maydis.

Water control (nuclease-free sterile water) was included in each run for both assays. To evaluate specificity of each assay, the heterologous Stenocarpella spp., six fungal pathogens of corn, one bacterial pathogen of corn, and two pathogenic fungi not known to attack corn were also included in each run (Table 1). Each reaction was performed three times.

Detection limit for conventional and real-time PCR. The detection limit for each assay was determined by serial 10-fold dilution of 
genomic DNA from pure fungal cultures and from corn seed. Dilutions ranged from 10 to $10 \times 10^{-6} \mathrm{ng} / \mu \mathrm{l}$ for $S$. maydis and 10 to $10 \times 10^{-3} \mathrm{ng} / \mu \mathrm{l}$ for $S$. macrospora. The PCR conditions for both assays described previously were used. Amplification was confirmed on a $1 \%(\mathrm{wt} / \mathrm{vol})$ agarose gel and by melting curve profile for conventional and real-time PCR, respectively.

\section{Results}

Fragments of the ITS region were successfully isolated from the two Stenocarpella spp. using primers ITS1F and ITS4 (gel not shown). The primer set Smay.F/Smay.R, specific for $S$. maydis, generated a single and specific PCR product of $1.7 \mathrm{~kb}$ (Fig. 1A). This PCR product was observed in all $82 \mathrm{~S}$. maydis isolates tested and in none of the $S$. macrospora isolated tested. No cross-amplification product was obtained when DNA from other fungal or bacterial pathogens was used (Fig. 1B). When DNA extracted directly from infected corn kernels and stalks (not pure culture) was tested using the conventional PCR set of primers, a specific PCR product of $1.7 \mathrm{~kb}$ was obtained (gel not shown).

The $S$. macrospora-specific primers Smac.F/Smac.R generated a single PCR product of 800 bp (Fig. 2A). This PCR product was observed only in the $15 \mathrm{~S}$. macrospora isolates tested, and DNA extracted from other fungal or bacterial isolates did not generate a PCR product (Fig. 2B). When DNA extracted directly from infected corn kernels and leaves (not pure culture) was tested using the conventional PCR set of primers, a specific PCR product of
800 bp was observed on the corn kernels DNA; however, for the DNA extracted from corn leaves, a faint band was obtained (gel not shown).

Primers designed for the real-time assay were tested first in a conventional PCR assay. Two PCR products of 500 and $800 \mathrm{bp}$ were generated by the primer sets RT.Smay.F/RT.Smay.R and RT.Smac.F/RT.Smac.R, respectively, for each target-species (gel not shown). No cross-amplification product was obtained when DNA from other fungal or bacterial isolates was tested.

The real-time PCR assay for $S$. maydis specifically amplified DNA from all $S$. maydis isolates tested (Fig. 3A). Positive $S$. maydis isolates had a range of melting peaks of 88.54 to $88.94^{\circ} \mathrm{C}$ (Fig. 3B and $\mathrm{C}$ ) and cycle threshold $\left(\mathrm{C}_{\mathrm{t}}\right)$ values of 23.18 to 26.16 (Fig. 3C). DNA extracted from corn kernels and stalks infected with S. maydis were tested with RT.Smay.F/RT.Smay.R primers, melting peaks were 88.74 and $88.94^{\circ} \mathrm{C}$, respectively (Fig. 3B and C), and $\mathrm{C}_{\mathrm{t}}$ values were 28.55 and 30.00 , respectively (Fig. 3C). The $S$. maydisspecific real-time PCR assay did not amplify DNA of any of the $S$. macrospora isolates. Negative control samples showed a different range of melting peaks ( 64 to $78.01^{\circ} \mathrm{C}$; Fig. 3B and C) compared with the $S$. maydis isolates. $\mathrm{C}_{\mathrm{t}}$ values from most of the negative controls were $\geq 30$; however, DNA of the nontarget species Aspergillus flavus and E. turcicum, reported $\mathrm{C}_{\mathrm{t}}$ values of 26.08 and 27.21 , respectively. The specific primers RT.Smac.F/RT.Smac.R produced an amplicon of the expected size for all S. macrospora isolates (Fig. 4A). S. macrospora isolates had a melting peak range of 89.39 to $89.80^{\circ} \mathrm{C}$

Table 2. Primer sequence used to identify isolates of Stenocarpella spp.

\begin{tabular}{llccc}
\hline Primer & \multicolumn{1}{c}{ Sequence 5' $\mathbf{3}^{\prime}$} & Annealing temperature $\left({ }^{\circ} \mathbf{C}\right)$ & Product size $(\mathbf{b p})$ & Product melt curve peak $\left({ }^{\circ} \mathbf{C}\right)$ \\
\hline Smay.F & CCTGCTATGCATAGGTCG & 52.6 & $\ldots$ & $\ldots$ \\
Smay.R & CAC CAG GCC GTT AAG CCT TA & 57.4 & 1,700 & $\ldots$ \\
RT.Smay.F & GTT TCC ATG ACC TGC TCA CG & 56.3 & $\ldots$ & $\ldots$ \\
RT.Smay.R & TGT TGC TCG GTT TCA GGC TTG & 58.4 & 500 & \\
Smac.F & GGG CAA ATT TTC TCG GAG G & 54 & 8 & \\
Smac.R & GCA GCT ATT CAG CGT TCA TC & 54.1 & $\ldots$ & $\ldots$ \\
RT.Smac.F & GGG CAA ATT TTC TCG GAG G & 54 & $\ldots$ & \\
RT.Smac.R & GCA GCT ATT CAG CGT TCA TC & 54.1 & 800 & \\
\hline
\end{tabular}

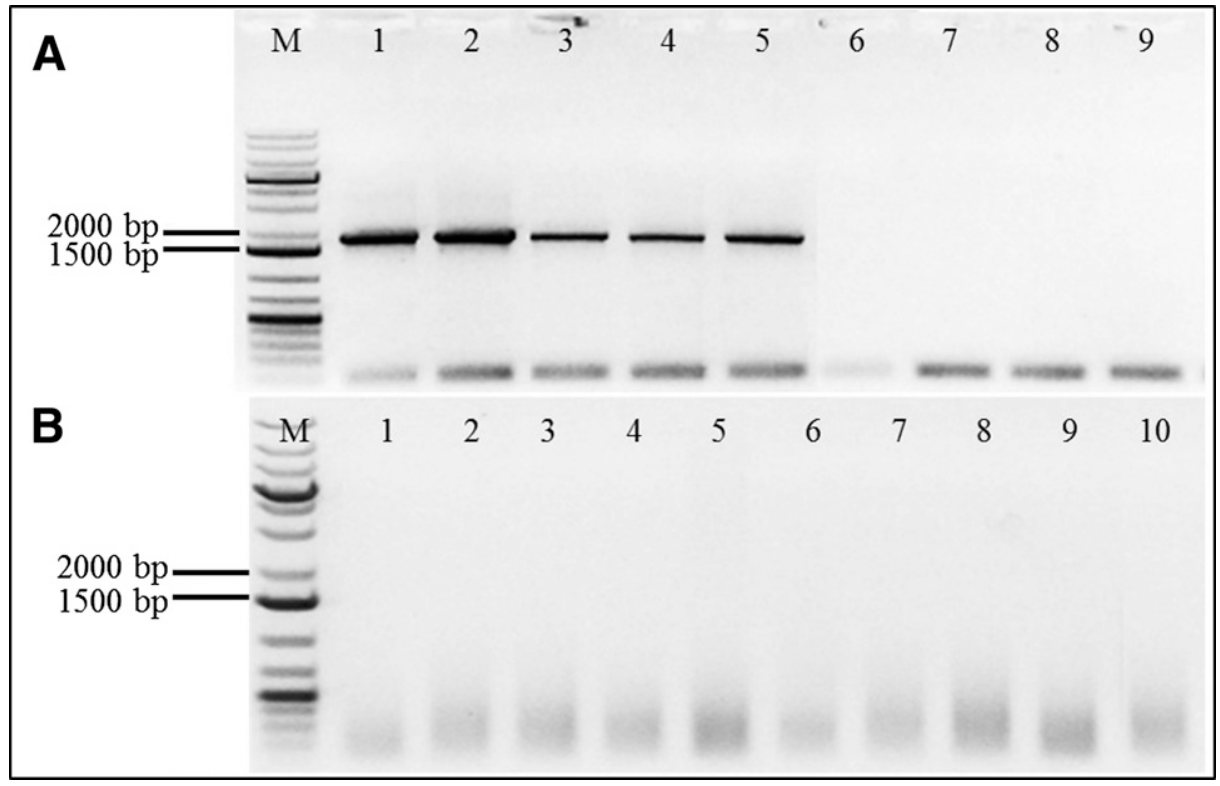

Fig. 1. Agarose gel electrophoresis of polymerase chain reaction products. A, Products of Stenocarpella maydis obtained with primers Smay.F/Smay.R. Lanes 1 to 5 : isolates 3-10-1, 3a.1, 4a.1.2, 7.1, and 10a.2, respectively; lane 6 to 8: S. macrospora isolates 1a.1.1, 1a, and 4b, respectively; lane 9: control (nuclease-free sterile water); lane M: molecular size marker (Life Technologies, Grand Island, NY). B, Products of other fungal and bacteria species obtained with primers Smay.F/SmayR. Lanes 1 to 9: Phoma spp., Diplodia pinea, Fusarium graminearum, Aspergillus flavus, Clavibacter michiganensis subsp. nebraskensis, Exserohilum turcicum, Colletotrichum graminicola, Macrophomina phaseolina, and Fusarium verticillioides, respectively; lane 10: control (nuclease-free sterile water; lane M: molecular size marker (Life Technologies). 


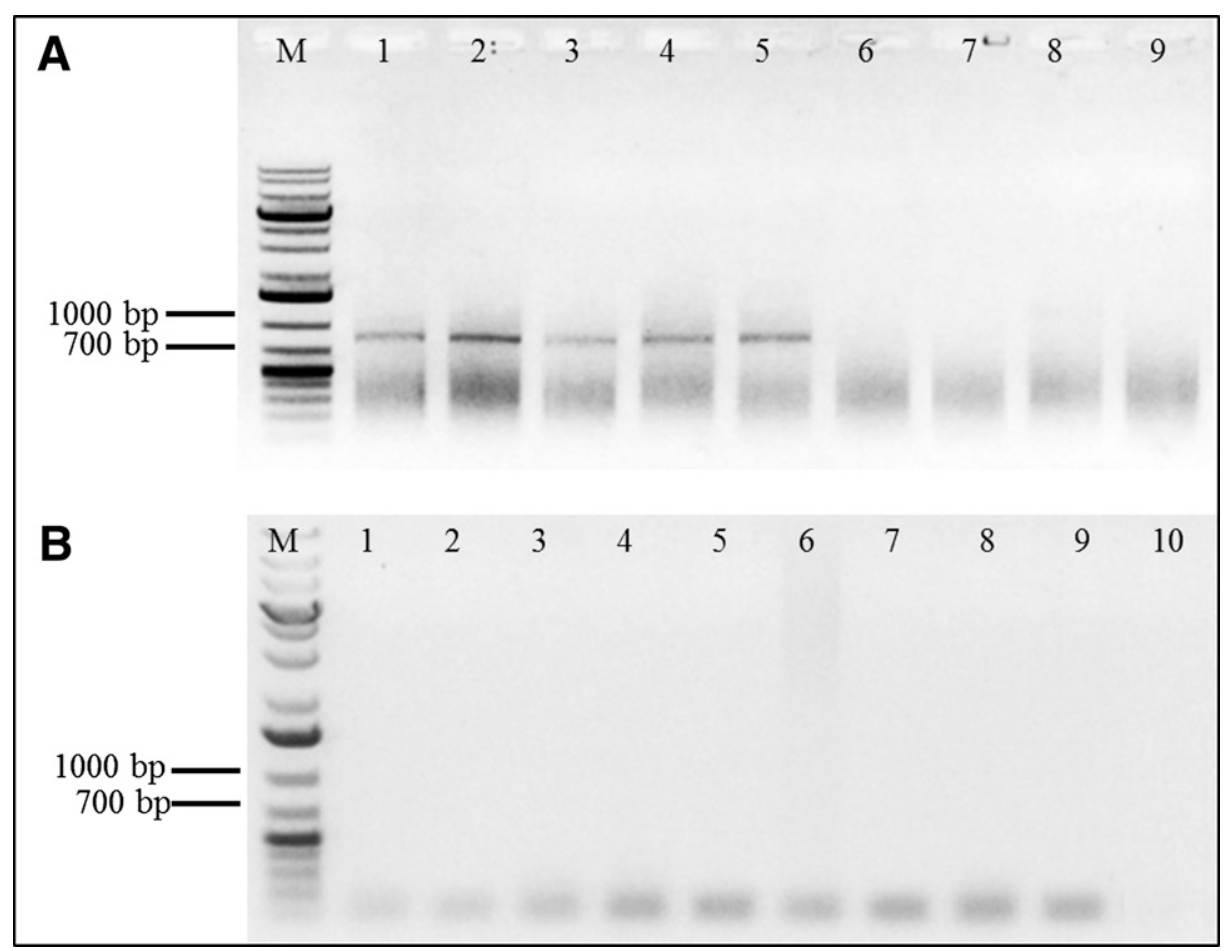

Fig. 2. Agarose gel electrophoresis of polymerase chain reaction products. A, Products of Stenocarpella macrospora obtained with primers Smac.F/Smac.R. Lanes 1 to 5: isolates 1b, 4a.2, 4b, 1a.1.1, and 1, respectively; lane 6 to 8: S. maydis isolates 2-2-1, 7.1, and 3a.1, respectively; lane 9: control (nuclease-free sterile water; lane M: molecular size marker (Life Technologies). B, Products of other fungal and bacteria species obtained with primers Smac.F/Smac.R. Lanes 1 to 9: Phoma spp., Diplodia pinea, Fusarium graminearum, Aspergillus flavus, Clavibacter michiganensis subsp. nebraskensis, Exserohilum turcicum, Colletotrichum graminicola, Macrophomina phaseolina, and Fusarium verticillioides, respectively; lane 10: control (nuclease-free sterile water; lane M: molecular size marker (Life Technologies).

A
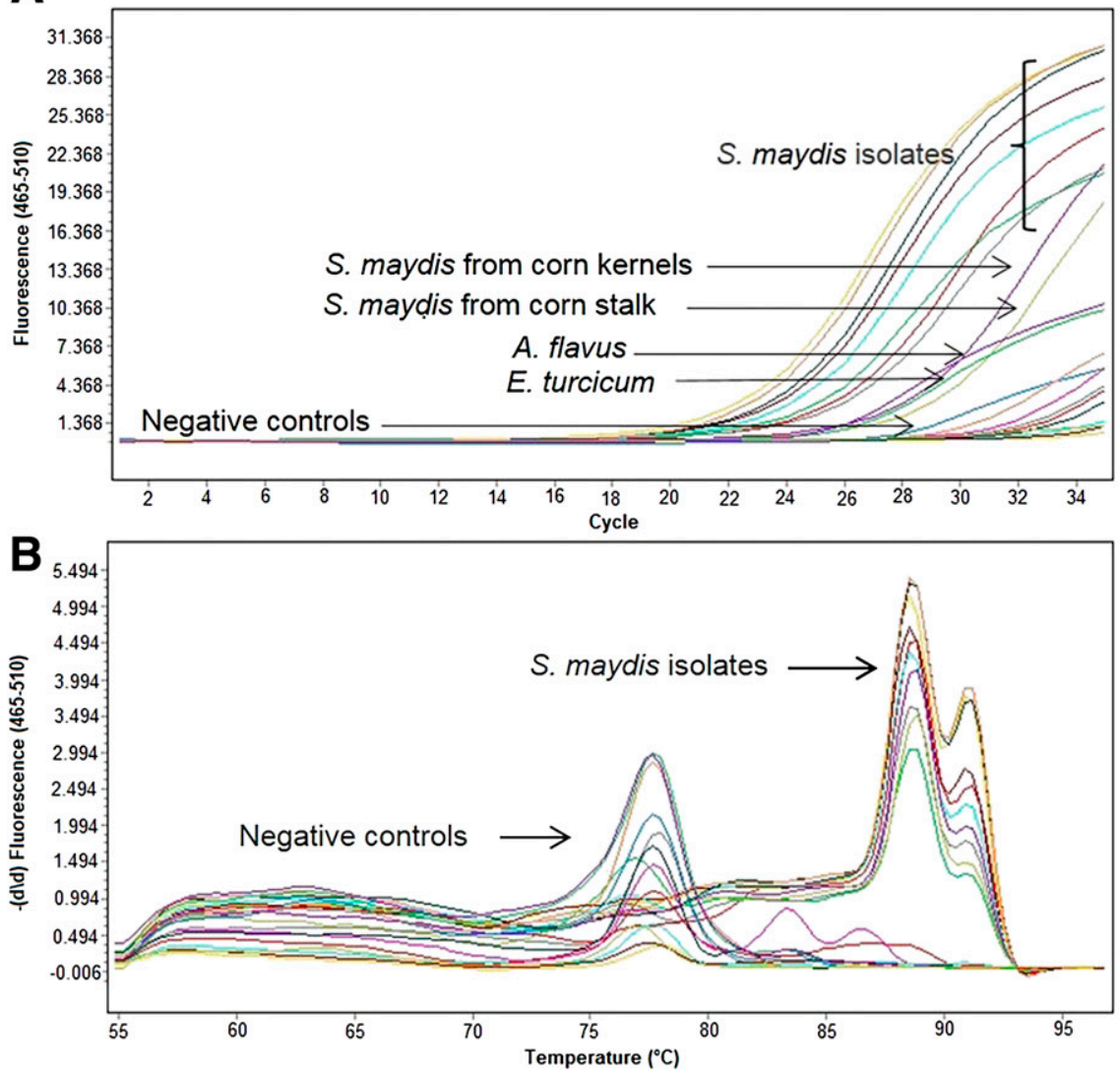

C

\begin{tabular}{|l|l|l|}
\hline \multicolumn{1}{|c|}{ Isolate $^{\mathrm{a}}$} & \multicolumn{1}{c|}{ Ct $^{\mathrm{b}}$} & Temperature \\
\hline 3b.1 & $25.98 \pm 0.15$ & 88.72 \\
\hline 3a.1 & $24.82 \pm 0.16$ & 88.89 \\
\hline 4b.1 & $26.16 \pm 0.04$ & 88.90 \\
\hline 10a.2 & $23.18 \pm 0.26$ & 88.70 \\
\hline 3.1 & $24.37 \pm 0.18$ & 88.54 \\
\hline 9 & $24.71 \pm 0.03$ & 88.91 \\
\hline 5.2 & $24.10 \pm 0.19$ & 88.66 \\
\hline 4.1 & $23.31 \pm 0.30$ & 88.64 \\
\hline Corn kernel & $28.55 \pm 0.41$ & 88.74 \\
\hline Corn stalk & 30.00 & 88.94 \\
\hline A. flavus & $27.21 \pm 0.20$ & 64.25 \\
\hline C. graminicola & 30.00 & 76.80 \\
\hline E. turcicum & $26.08 \pm 0.02$ & 77.73 \\
\hline F. graminearum & 30.00 & 77.64 \\
\hline F. verticillioides & 30.00 & 73.85 \\
\hline Cmn ${ }^{\text {c }}$ & 30.00 & 78.01 \\
\hline M. phaseolina & 30.00 & 77.43 \\
\hline D. pinnea & 30.00 & 77.61 \\
\hline Phoma spp. & 30.00 & 77.68 \\
\hline S. macrospora & 30.00 & 77.45 \\
\hline Water & 30.00 & 77.65 \\
\hline & & \\
\hline
\end{tabular}

Fig. 3. Melting curve analysis for Stenocarpella maydis using real-time polymerase chain reaction (PCR) assay. A, Amplification curves of S. maydis isolates and controls obtained with primers RT.Smay.F/RT.Smay.R. B, Melting curve analysis of the same samples shows the presence of the specific PCR product. $\mathrm{C}$, Comparison chart with cycle threshold $\left(\mathrm{C}_{t}\right)$ values and melting temperatures. Superscript a: DNA extracted for other fungi isolated that are not the target of this assay and water are identified as negative controls. Superscript $\mathrm{b}: \mathrm{C}_{\mathrm{t}}$ values \pm standard deviation. Superscript c: $\mathrm{Cmn}=$ Clavibacter michiganensis subsp. nebraskensis 
(Fig. 4B and C), and $\mathrm{C}_{\mathrm{t}}$ values of 18.31 to 21.69 (Fig. 4C). DNA extracted from infected corn kernels and leaves with $S$. macrospora were tested with RT.Smac.F/RT.Smac.R primers, melting peaks were 89.18 and $88.25^{\circ} \mathrm{C}$, respectively, and $C_{t}$ values were 22.31 and 23.89, respectively (data not shown). The $S$. macrosporaspecific assay did not amplify DNA from any $S$. maydis isolates or negative controls included in the assay (melting peak range of 76.74 to $83.28^{\circ} \mathrm{C}$ and $\mathrm{C}_{\mathrm{t}}$ values $=25.00$; Fig. $4 \mathrm{~B}$ and $\mathrm{C}$ ).

Detection limits of $S$. maydis in conventional and real-time PCR were $0.01 \mathrm{ng} / \mu \mathrm{l}$ with Smay.F/SmayR primers (Fig. $5 \mathrm{~A}$ ) and $0.001 \mathrm{ng} / \mu \mathrm{l}$ with RT.Smay.F/RT.Smay.R primers (Fig. 5A). The detection limits of $S$. macrospora in conventional and real-time assays were $0.1 \mathrm{ng} / \mu \mathrm{l}$ with Smac.F/Smac.R primers (Fig. 5B), and $1 \mathrm{ng} / \mu \mathrm{l}$ with RT.Smac.F/RT.Smac primers (Fig. 5B). Detection limits of DNA extracted from infected corn seed were $10 \mathrm{ng} / \mu \mathrm{l}$ for $S$. maydis and $S$. macrospora in conventional PCR, and $1 \mathrm{ng} / \mu \mathrm{l}$ for $S$. maydis and $S$. macrospora in real-time PCR (data not shown).

\section{Discussion}

This is the first study to successfully develop multiple PCR assays with the specificity to distinguish $S$. maydis from $S$. macrospora. These pathogens are difficult to distinguish based on pathogen signs and disease symptoms, and previous diagnostic assays have been time consuming or nonspecific. Both conventional and real-time assays were able to distinguish between $S$. maydis and $S$. macrospora isolates collected from several states in the United States Corn Belt.

Real-time assays developed and validated here demonstrate that these techniques can be used to assess $S$. macrospora and $S$. maydis presence in both pure culture and in infected plant tissue. In this assay, two corn pathogens, A. flavus and E. turcicum, had slightly higher $\mathrm{C}_{\mathrm{t}}$ values (26.08 and 27.21, respectively) than the range of $S$. maydis isolates (23.18 to 26.16). In the $S$. macrospora assay, Phoma spp. had a $C_{t}$ value of 19.95 , which is in the $C_{t}$ range of $S$. macrospora isolates (18.31 to 21.69). However, in both assays, the identity of each respective organism was easily differentiated from nontarget pathogens by examining the melting profile of the amplified products. When SYBR Green is used for detection, it is difficult to determine whether the $C_{t}$ value obtained is due to nontarget amplicons or to nonspecific products. Because of this, identification of isolates using these protocols should be based only on the analysis of the melting curves. Melting curves and peak locations clarify target species as positive samples and nontarget species as negative samples. For instance, melting curve peaks for $A$. flavus and E. turcicum are 64.25 and $77.73^{\circ} \mathrm{C}$, respectively, which are lower than the range of $S$. maydis isolates $\left(88.54\right.$ to $\left.89.94^{\circ} \mathrm{C}\right)$. Phoma spp. had a melting curve peak of $83.28^{\circ} \mathrm{C}$, compared with the range of 89.39 to $89.80^{\circ} \mathrm{C}$ for $S$. macrospora isolates. Schroeder et al. (43) described the advantage that real-time PCR offers by observing the melting curves of each product. Melting curves are based on the GC amount, length, and sequence that each sample contains and, for that reason, melting curve peaks for the target Stenocarpella spp. may vary slightly when implemented in other laboratories (39).

SYBR Green was selected for use in the real-time assays due to the relative simplicity and low cost of the product $(4,5,34)$. Buh Gašparič et al. (4) compared nine different real-time chemistries and concluded that SYBR Green is suitable for use in both qualitative and quantitative detection assays. However, SYBR Green binds with all doublestranded DNA, including nontarget amplicons as well as nonspecific products. This can result in florescence in samples that are free of the target pathogen (39). This could explain why florescence was

A

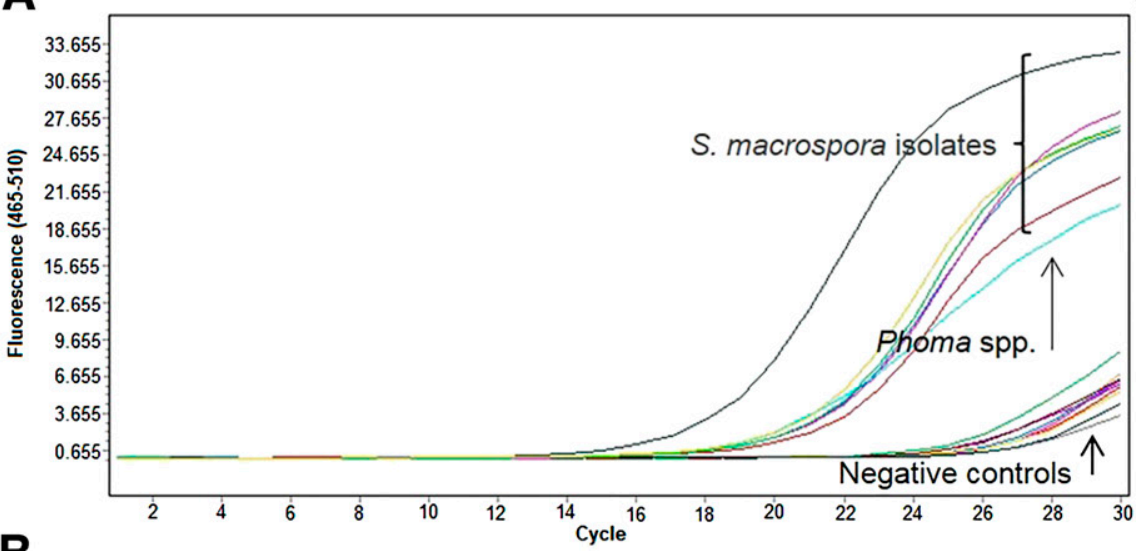

B

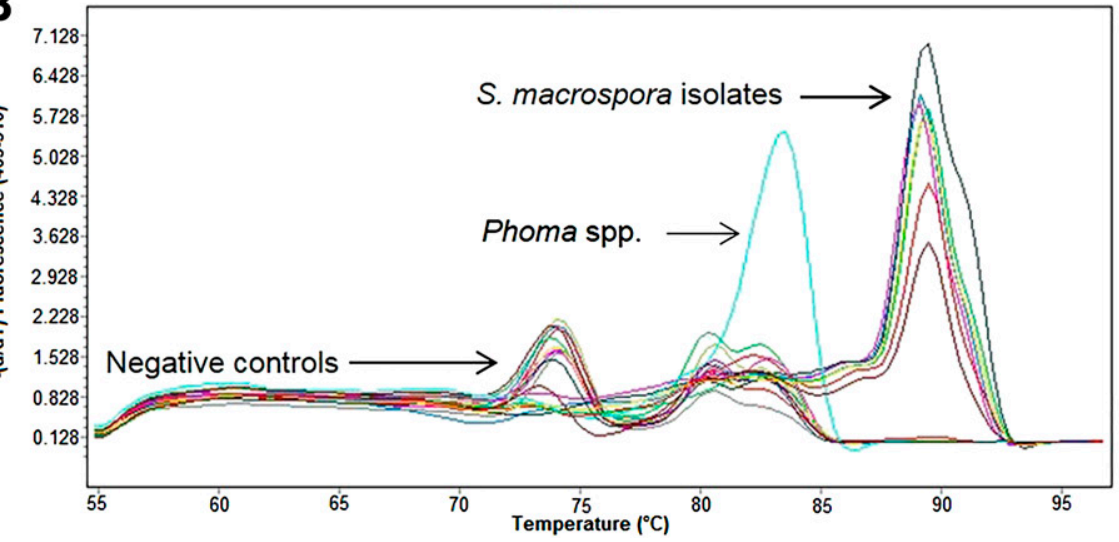

C

\begin{tabular}{|l|l|c|}
\hline \multicolumn{1}{|c|}{ Isolate $^{\mathrm{a}}$} & \multicolumn{1}{c|}{ Ct $^{\mathrm{b}}$} & Temperature \\
\hline P11-2.1a.2 & $21.24 \pm 0.03$ & 89.39 \\
\hline 2.1a & $21.69 \pm 0.41$ & 89.60 \\
\hline 1a.1.1 & $21.11 \pm 0.09$ & 89.40 \\
\hline 4c.1.1 & $21.20 \pm 0.49$ & 89.71 \\
\hline 10.1b & $21.15 \pm 0.51$ & 89.38 \\
\hline 4a.2 & $20.35 \pm 0.27$ & 89.79 \\
\hline 4b & $18.31 \pm 0.30$ & 89.80 \\
\hline A. flavus & 25.00 & 83.19 \\
\hline C. graminicola & 25.00 & 74.13 \\
\hline E. turcicum & 25.00 & 74.08 \\
\hline F. graminearum & 25.00 & 74.13 \\
\hline F. verticillioides & 25.00 & 73.74 \\
\hline Cmnc & 25.00 & $\mathrm{NA}$ \\
\hline M. phaseolina & 25.00 & 74.30 \\
\hline D. pinnea & 25.00 & 73.99 \\
\hline S.maydis & 25.00 & 73.00 \\
\hline Phoma spp. & $19.95 \pm 0.26$ & 83.28 \\
\hline Water & 25.00 & \\
\hline
\end{tabular}

Fig. 4. Melting curve analysis for Stenocarpella macrospora using real-time polymerase chain reaction (PCR) assay. A, Amplification curves of S. macrospora isolates and controls obtained with primers RT.Smac.F/RT.Smac.R. B, Melting curve analysis of the same samples shows the presence of the specific PCR product. C, Comparison chart with cycle threshold $\left(\mathrm{C}_{\mathrm{t}}\right)$ values and melting temperatures. Superscript a: DNA extracted for other fungi isolated that are not the target of this assay and water are identified as negative controls. Superscript b: $\mathrm{C}_{\mathrm{t}}$ values \pm standard deviation. Superscript c: $\mathrm{Cmn}=$ Clavibacter michiganensis subsp. nebraskensis. 
observed in certain real-time PCR assays of nontarget organisms for which no amplicon was detected in conventional PCR assays. This potential disadvantage is remedied by examining the melting profile at the end of the real-time assay $(39,43)$. Other assays using real-time PCR employing the fluorescent dye SYBR Green for the detection and diagnosis of plant pathogens have shown that the analysis of the melting profile allowed differentiation of the target with the nontarget species. Tessitori et al. (49) was able to confirm and differentiate two different citrus viroids, Citrus exocortis viroid and Citrus viroid-IIb, by the use of melting temperatures and their melting peaks. Torres et al. (50) also described the advantage of using the melting curve analysis to differentiate three different apple proliferation phytoplasmas ('Candidatus Phytoplasma pyri', 'Ca. P. pronorum', and 'Ca. P. mali') by their melting peaks. Therefore, we concluded that the use of SYBR Green and the analysis of the melting profile using real-time PCR is a reliable tool for the diagnosis of Stenocarpella spp.

$S$. maydis and S. macrospora were identified directly from corn kernels with both conventional and real-time PCR assays. Amplified bands were reliable enough to confirm the presence of both Stenocarpella spp. Positive confirmation in infected corn seed using the real-time assay was based on the melting peak observed in the melting curve analysis. Samples were concluded to be positive for $S$. maydis and $S$. macrospora if the melting peak was located at 88 and $89^{\circ} \mathrm{C}$, respectively. The use of both assays on DNA samples extracted from infected corn seed simplifies the identification of this pathogen and increases the utility of these assays in seedmonitoring programs. However, weak bands were observed in the conventional PCR assay when DNA was extracted directly from corn leaves infected with $S$. macrospora. Because these amplified bands were not as strong as those observed when $S$. macrospora DNA was amplified directly from corn kernels or from fungal cultures, we cannot reliably confirm $S$. macrospora directly from leaf tissue with the conventional PCR assay. However, both conventional and real-time PCR assays were able to reliably detect $S$. macrospora fungal presence at a detection limit of 0.1 and $1 \mathrm{ng} / \mu \mathrm{l}$, respectively, from fungal culture, and 10 and $1 \mathrm{ng} / \mu \mathrm{l}$, respectively, from infected corn seed. Detection of fungal presence in corn seed using DNA extracted from cultures or directly from infected tissue would be the primary use of these assays in regulatory agencies testing for seed quality, and incubation of infected tissue to increase the amount of DNA extracted from the pathogen may improve sensitivity in the assay (2). Further testing is needed to determine whether amplification of $S$. macrospora from infected leaves can be achieved with a conventional PCR assay.

Infected corn seed has been identified as an important source of inoculum for both Stenocarpella spp. $(7,26,27)$, and can be regulated due to the potential for importing mycotoxin-affected grain into an area $(11,16,28,32,38)$. Barrocas et al. (2) described the necessity of having a specific and accurate method for the identification of both Stenocarpella spp. for the Brazilian seed certification program, where $S$. maydis is listed as an RNQP and the Ministry of Agriculture has proposed that imported seed lots of certified seed may not contain more than $2 \% \mathrm{~S}$. maydis (Administrative Regulation Number 47 of 19 February 2009). Inaccurate or unreliable diagnostic methods can negatively impact seed commercialization. The assays developed in this study can be useful tools in areas where $S$. maydis has been categorized as an RNQP.
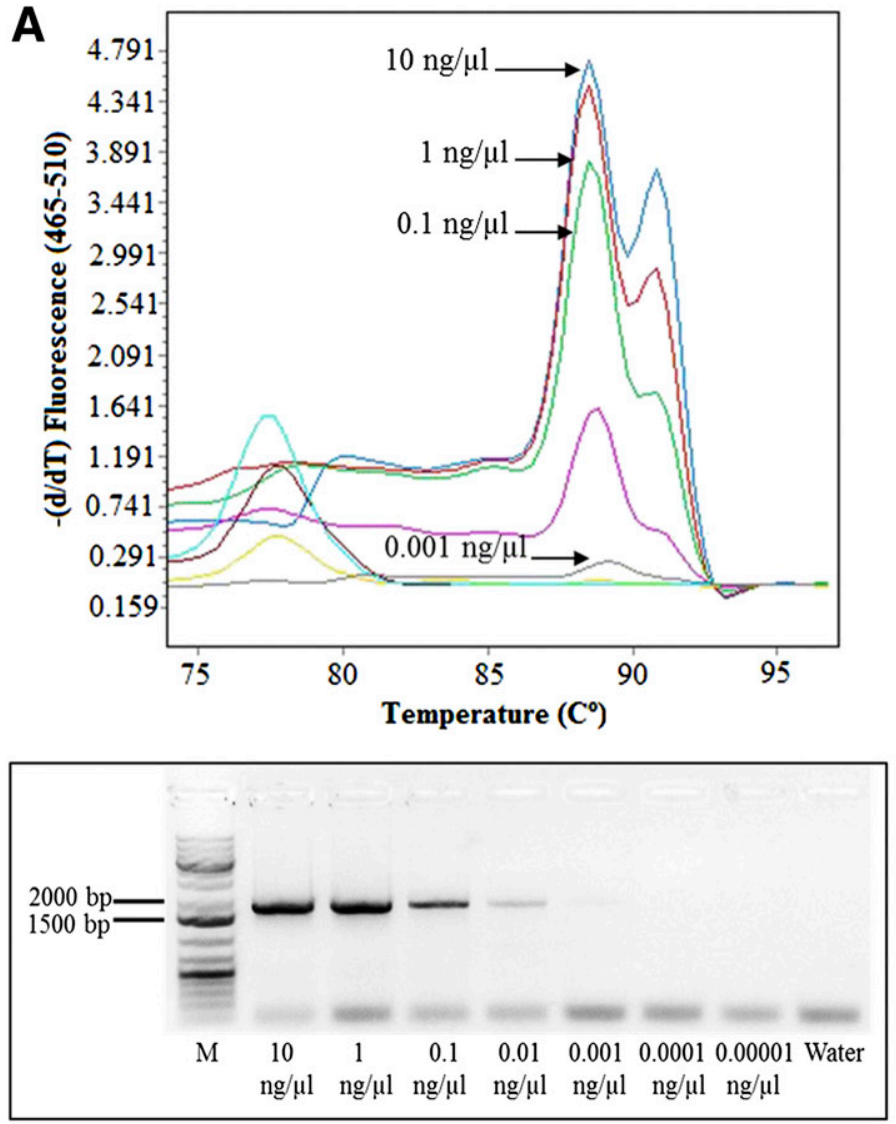
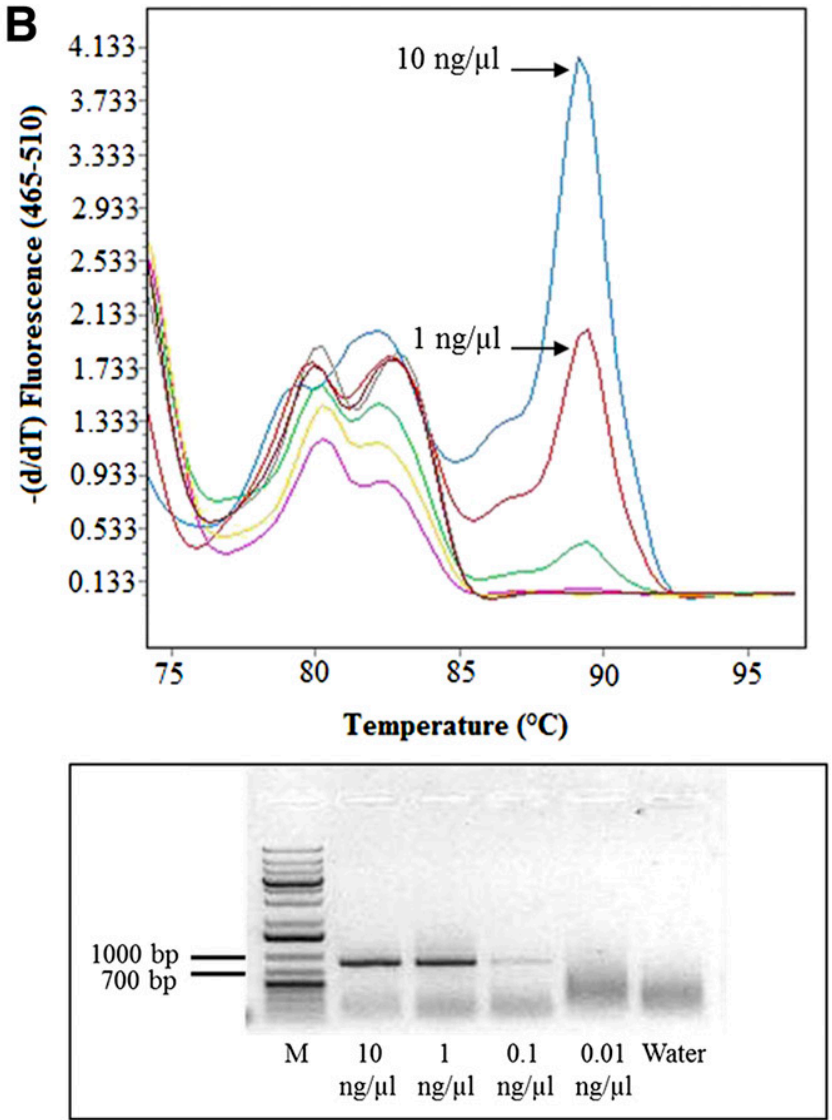

Fig. 5. A, Dilution series for Stenocarpella maydis real-time (top image) and conventional (bottom/gel image) polymerase chain reaction (PCR) assays. Ten-fold dilutions were performed in each assay, with an initial concentration of $10 \mathrm{ng} / \mu \mathrm{l}$ to a final concentration of $0.00001 \mathrm{ng} / \mu \mathrm{l}$. Gel image includes lane M: molecular size marker (Life Technologies, Grand Island, NY) and nuclease-free sterile water as control. B, S. macrospora real-time (top image) and conventional (bottom/gel image) PCR assays. Ten-fold dilutions were performed in each assay, with an initial concentration of $10 \mathrm{ng} / \mu \mathrm{l}$ to a final concentration of $0.01 \mathrm{ng} / \mu \mathrm{l}$. Gel image includes lane M: molecular size marker (Life Technologies) and nuclease-free sterile water as control. 


\section{Acknowledgments}

We thank C. P. Woloshuk for providing access to the $S$. maydis genome and for providing comments on the manuscript; G. Bergstrom, C. Bradley, T. Hughes, L. Sweets, and H. Young-Kelly for providing isolates; M. C. Aime for helpful discussion during the development of this study; N. Anderson for laboratory assistance and comments on the manuscript; and R. Koch and $Z$. Sexton for valuable comments and suggestions on the manuscript. Financial support was provided by the United States Department of Agriculture NIFA AFRI grant number 2010-85117-20607.

\section{Literature Cited}

1. Adipala, E., Lipps, P. E., and Madden, L. V. 1993. Reaction of maize cultivars from Uganda to Exserohilum turcicum. Phytopathology 83:217-223.

2. Barrocas, E. N., Machado, J. C., Almeida, M. F., Botelho, L. S., and Von Pinho, É. V. R. 2012. Sensibility of the PCR technique in the detection of Stenocarpella sp. associated with maize seeds. Rev. Bras. Sementes 34: 218-224.

3. Bradley, C. A., Pedersen, D. K., Zhang, G. R., and Pataky, N. R. 2010. Occurrences of diplodia leaf streak caused by Stenocarpella macrospora on corn (Zea mays) in Illinois. Plant Dis. 94:1262.

4. Buh Gašparič, M., Tengs, T., La Paz, J., Holst-Jensen, A., Pla, M., Esteve, T., Žel, J., and Gruden, K. 2010. Comparison of nine different real-time PCR chemistries for qualitative and quantitative applications in GMO detection. Anal. Bioanal. Chem. 396:2023-2029.

5. Cao, H., and Shockey, J. M. 2012. Comparison of TaqMan and SYBR Green qPCR methods for quantitative gene expression in tung tree tissues. J. Agric. Food Chem. 60:12296-12303.

6. Casa, R. T., Reis, E. M., and Zambolim, L. 2006. Doenças do Milho Causadas por Fungos do Gênero Stenocarpella. Fitopatol. Bras. 31:427-439.

7. Casa, R. T., Reis, E. M., and Zambolim, L. 1988. Fungos associados a semente de milho produzida nas Regioes Sul e sudesde do Brasil. Fitopatol. Bras. 23: 370-373.

8. Casa, R. T., and Zambolim, L. 1997. Diplodia maydis e Diplodia macrospora associados à semente de milho. Dissertação de Mestrado, Universidade Federal de Viçosa, Viçosa, Brazil.

9. Crous, P. W., Slippers, B., Wingfield, M. J., Rheeder, J., Marasas, W. F. O., Philips, A. J. L., Alves, A., Burgess, T., Barber, P., and Groenewald, J. Z. 2006. Phylogenetic lineages in the Botryosphaeriaceae. Stud. Mycol. 55:235-253.

10. Cutler, H. G., Crumley, F. G., Cox, R. H., Cole, R. J., Dorner, J. W., Latterell, F. M., and Rossi, A. E. 1980. Diplodiol: A new toxin from Diplodia macrospora. J. Agric. Food Chem. 28:135-138.

11. Darvall, P. M. 1964. Mouldy corn cobs, a danger to cows. Queensl. Agric. J. 90:692-693.

12. Earle, F. S. 1897. New species of fungi imperfecti from Alabama. Bull. Torrey Bot. Club 24:28-32

13. Eddins, A. H. 1930. Dry rot of corn caused by Diplodia macrospora Earle. Phytopathology 20:439-447.

14. Gardes, M., and Bruns, T. D. 1993. ITS primers with enhanced specificity for basidiomycetes - application to the identification of mycorrhizae and rusts. Mol. Ecol. 2:113-118.

15. Johann, H. 1935. Diplodia macrospora on corn in Brazil. Plant Dis. Rep. 19:9-10.

16. Kellerman, T. S., Prozesky, L., Schultz, R. A., Rabie, C. J., Van Ark, H., Maartens, B. P., and Lübben, A. 1991. Perinatal mortality in lambs of ewes exposed to cultures of Diplodia maydis (= Stenocarpella maydis) during gestation. Onderstepoort J. Vet. Res. 58:297-308.

17. Kellerman, T. S., Rabie, C. J., Van der Westhuizen, G. C., Kriek, N. P., and Prozesky, L. 1985. Induction of diplodiosis, a neuromycotoxicosis, in domestic ruminants with cultures of indigenous and exotic isolates of Diplodia maydis. Onderstepoort J. Vet. Res. 52:35-42.

18. Kriek, N. P. J., and Marasas, W. F. O. 1979. Toxicity of Diplodia macrospora to laboratory animals. Food Cosmet. Toxicol. 17:233-236.

19. Latterell, F. M., and Rossi, A. E. 1983. Stenocarpella macrospora (=Diplodia macrospora) and $S$. maydis (=D. maydis) compared as pathogens of corn. Plant Dis. 67:725-729.

20. Latterell, F. M., Rossi, A. E., and Moreno, R. 1976. Diplodia macrospora: A potentially serious pathogen of corn in the U.S.? (Abstr.) Proc. Am. Phytopathol. Soc. 3:28.

21. Lievens, B., and Thomma, B. P. H. J. 2005. Recent developments in pathogen detection arrays: Implications for fungal plant pathogens and use in practice. Phytopathology 95:1374-1380.

22. Lipps, P. E., and Mills, D. R. 2002. Diplodia ear rot of corn. The Ohio State University Extension Fact Sheet AC-0046-01. Online publication. http:// ohioline.osu.edu/ac-fact/0046.html.

23. Marasas, W. 1977. The genus Diplodia. Pages 119-128 in: Mycotoxic Fungi, Mycotoxins, Mycotoxicoses. An Encyclopedic Handbook, Vol. 1. T. D. Wyllie and L. G. Morehouse, eds. Marcel Decker, Inc., NY.

24. Marasas, W. F. O., and Van der Westhuizen, G. C. A. 1979. Diplodia macrospora: The cause of a leaf blight and cob rot of maize (Zea mays) in South Africa. Phylophylactica 11:61-64.

25. Mario, J. L., and Reis, E. M. 2001. Método simples para diferenciar Diplodia macrospora de D. maydis em testes de patologia de sementes de milho. Fitopatol. Bras. 26:670-672.
26. McGee, D. C. 1988. Maize Diseases: A Reference Source for Seed Technologists. American Phytopathological Society, St. Paul, MN.

27. McNew, G. L. 1937. Crown infection of corn by Diplodia zeae. Iowa Agric. Exp. Stn. Res. Bull. 216. Ames.

28. Mitchell, D. T. 1919. Poisoning of cattle by Diplodia-infected maize. S. Afr. J Sci. 16:446-452.

29. Morant, M. A. 1988. Stenocarpella (Diplodia) maydis: Influence of nitrogen and inoculation on biochemical components of maize stalk. Ph.D. diss. Botany and Plant Pathology Department, Purdue University, West Lafayette, IN.

30. Morant, M. A., Warren, H. L., and Vonqualen, S. K. 1993. A synthetic medium for mass-production of pycnidiospores of Stenocarpella maydis. Plant Dis. 77:424-426

31. Mueller, D., and Wise, K. A. 2012. Corn disease loss estimates from the United States and Ontario, Canada-2012. Purdue Ext. Publ. BP-96-12-W. Online publication. https://www.extension.purdue.edu/extmedia/BP/BP-96 12-W.pdf

32. Odriozola, E., Odeon, A., Canton, G., Clemente, G., and Escande, A. 2005 Diplodia maydis: A cause of death of cattle in Argentina. N. Z. Vet. J. 53 160-161.

33. Pascual, C. B., and Relevante, C. A. 2003. Cultural and molecular characterization of Stenocarpella macrospora (Earle) Sutton causing leaf blight, ear rot and stalk rot in maize. J. Trop. Plant Pathol. 39:36-42.

34. Ponchel, F., Toomes, C., Bransfield, K., Leong, F. T., Douglas, S. H., Field, S. L., Bell, S. M., Combaret, V., Puisieux, A., and Mighell, A. J. 2003. Real-time PCR based on SYBR-Green I fluorescence: An alternative to the TaqMan assay for a relative quantification of gene rearrangements, gene amplifications and micro gene deletions. BMC Biotechnol. 3:18

35. Rao, S. K., and Achar, P. N. 2001. Screening and in vitro production of diplodiatoxin from the isolates of Stenocarpella maydis and its toxigenic effect on bacterial strains. Indian J. Exp. Biol. 39:1243-1248.

36. Reis, E. M., Casa, R. T., and Bresolin, A. C. R. 2004. Manual de diagnose e controle de doenças do milho, 2nd ed. Graphel Gráfica e Editora Lages, Santa Catarina, Brazil.

37. Riet-Correa, F., Mendez, M. C., and Schild, A. L. 1984. Page 35 in: Laboratório Regional de Diagnóstico. Doenças diagnosticadas no ano 1983. Editora da Universidade, Pelotas, Brazil.

38. Riet-Correa, F., Schild, A. L., and Fernandes, C. G. 1998. Enfermidades do sistema nervoso dos ruminantes no sul do Rio Grande do Sul. Cienc. Rural 28:341-348

39. Ririe, K. M., Rasmussen, R. P., and Wittwer, C. T. 1997. Product differentiation by analysis of DNA melting curves during the polymerase chain reaction. Anal. Biochem. 245:154-160.

40. Romero Luna, M. P. 2012. Managing Diplodia ear rot in corn: Short and longterm solutions. M.S. thesis, Botany and Plant Pathology Department, Purdue University, West Lafayette, IN.

41. Rossouw, J. D., Pretorius, Z. A., Silva, H. D., and Lamkey, K. R. 2009. Breeding for resistance to Stenocarpella ear rot in maize. Plant Breed. Rev. 31:223-246

42. Saghai-Maroof, M. A., Soliman, K. M., Jorgensen, R. A., and Allard, R. A 1984. Ribosomal DNA spacer length in barley: Mendelian inheritance, chromosomal location, and population dynamics. Proc. Natl. Acad. Sci. USA 81:8014-8018.

43. Schroeder, K. L., Okubara, P. A., Tambong, J. T., Lévesque, C. A., and Paulitz, T. C. 2006. Identification and quantification of pathogenic Pythium spp. from soils in Eastern Washington using real-time polymerase chain reaction. Phytopathology 96:637-647.

44. Siqueira, C. S., Barrocas, E. N., Machado, J. C., Silva, U. A., and Dias, I. E. 2014. Effects of Stenocarpella maydis in seeds and in the initial development of corn. J. Seed Sci. 36:79-86.

45. Snyman, L. D., Kellerman, T. S., Vleggaar, R., Flett, B. C., Basson, K. M., and Schultz, R. A. 2011. Diplonine, a neurotoxin isolated from cultures of the fungus Stenocarpella maydis (Berk.) Sacc. that induces diplodiosis. J. Agric. Food Chem. 59:9039-9044.

46. Steyn, P. S., Wessels, P. L., Holzapfel, C. W., Potgieter, D. J. J., and Louw, W. K. A. 1972. The isolation and structure of a toxic metabolite from Diplodia maydis (Berk.) SACC. Tetrahedron 28:4775-4785.

47. Sutton, B. C., and Waterston, J. M. 1966. Diplodia macrospora. CMI Descriptions of pathogenic fungi and bacteria. Set 9. No. 83. CAB International, Wallingford, UK

48. Sutton, B. C., and Waterston, J. M. 1966. Diplodia maydis. CMI Descriptions of pathogenic fungi and bacteria. Set 9. No. 84. CAB International, Wallingford, UK

49. Tessitori, M., Rizza, S., Reina, A., and Catara, V. 2005. Real-time RT-PCR based on SYBR-Green I for the detection of citrus exocortis and citru cachexia diseases. Pages 456-459 in: Proc. 16th Conf. Int. Organ. Citrus Virol. M. E. Hilf, N. Duran-Vila, and M. A. Rocha-Peña, eds. IOCV, Riverside, CA.

50. Torres, E., Bertolini, E., Cambra, M., Montón, C., and Martín, M. P. 2005. Real-time PCR for simultaneous and quantitative detection of quarantine phytoplasmas from apple proliferation (16SrX) group. Mol. Cell. Probes 19 334-340. 
51. Vincelli, P. 1997. Ear rot of corn caused by Stenocarpella maydis (=Diplodia maydis). Univ. Kentucky Coop. Ext. Serv. PPA-43. Online publication. http:// www2.ca.uky.edu/agc/pubs/ppa/ppa43/ppa43.htm

52. Vincelli, P. 2011. Diplodia leaf streak of corn. Pages 2-3 in: Kentucky Pest News No. 1277. Univ. Kentucky Coop. Ext. Serv. Online publication. http://www2.ca.uky.edu/agcollege/plantpathology/extension/KPN\%20Site\% 20Files/pdf/kpn1277.pdf

53. White, D. G. 1999. Page 44 in: Compendium of Corn Diseases, 3rd ed. American Phytopathological Society, St. Paul, MN.

54. White, T., Bruns, T., Lee, S., and Taylor, J. 1990. Amplification and direct sequencing of fungal ribosomal RNA genes for phylogenetics. Pages 315-322 in: PCR Protocols: A Guide to Methods and Applications.
M. Innis, D. Gelfand, J. Shinsky, and T. White, eds. Academic Press, New York.

55. Wicklow, D. T., Rogers, K. D., Dowd, P. F., and Gloer, J. B. 2011. Bioactive metabolites from Stenocarpella maydis, a stalk and ear rot pathogen of maize. Fungal Biol. 115:133-142.

56. Wise, K. A. 2011. Northern corn leaf blight. Diseases of corn. Purdue Univ. Purdue Ext. BP-84-W. Online publication. https://www.extension.purdue. edu/extmedia/BP/BP-84-W.pdf

57. Xia, Z., and Achar, P. N. 2001. Random amplified polymorphic DNA and polymerase chain reaction markers for the differentiation and detection of Stenocarpella maydis in maize seeds. J. Phytopathol. 149: $35-44$. 